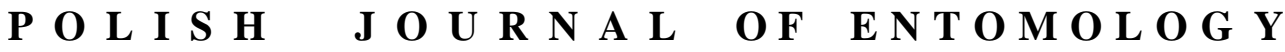

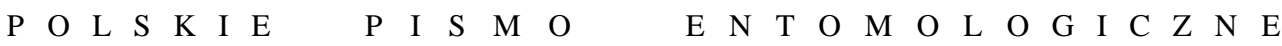

VOL. 84: $259-269$

Lublin

30 December 2015

DOI: $10.1515 /$ pjen-2015-0022

\section{New genus and species of Aleyrodidae from Eocene Baltic amber (Hemiptera: Sternorrhyncha: Aleyrodomorpha)*}

\author{
JOWITA DrohoJowsKA ${ }^{1}$, EvgENY E. PERKOVSKY ${ }^{2}$, JACEK SZWEDO ${ }^{3}$ \\ ${ }^{1}$ Department of Zoology, University of Silesia, 9, Bankowa, PL40-007 Katowice, Poland, \\ e-mail: jowita.drohojowska@us.edu.pl \\ ${ }^{2}$ Schmalhausen Institute of Zoology, National Academy of Sciences of Ukraine, 15, Bogdan \\ Khmelnitski Street, Kiev 01601, Ukraine, e-mail: perkovsk@gmail.com \\ ${ }^{3}$ Department of Invertebrate Zoology and Parasitology, University of Gdańsk, 59, Wita \\ Stwosza, PL80-308 Gdańsk, Poland, e-mail: jacek.szwedo@ biol.ug.edu.pl
}

\begin{abstract}
A new genus Rovnodicus gen. n., with new species Rovnodicus wojciechowskii sp. n. is described from Eocene Rovno amber, Ukraine. It is placed in the subfamily Aleurodicinae. It is the first whitefly from this fossil source. Its morphological features and taxonomic position with respect to other Aleurodicinae from the Eocene are briefly discussed. The article outlines the influences of this finding on discussions of the origin, age and taxonomic similarities between Baltic amber from Ukraine and that from the Gulf of Gdańsk and Bitterfeld as well as on palaeoecological reconstructions of the fossil site. The name 'Aleurochiton eozaenicus WEIGELT 1940', mentioned as the fossil puparium of a whitefly from the Middle Eocene Geiseltal Fossillagerstätte appears to be nomen nudum.
\end{abstract}

KEY WORDS: Rovnodicus gen. n., Rovnodicus wojciechowskii sp. n., 'Aleurochiton eozaenicus': WEIGELT 1940 nomen nudum, Aleyrodidae, whiteflies, Baltic amber, Rovno, Ukraine, new genus, new species, fossil, taxonomy.

\footnotetext{
* The paper is dedicated to Prof. Wacław WOJCIECHOWSKI in recognition of his great contribution to the taxonomy and faunistics of Hemiptera.
} 


\section{INTRODUCTION}

The Aleyrodidae WeSTWOOD, 1840, commonly known as whiteflies, is a family of Sternorrhyncha (Hemiptera) common in tropical and subtropical zones worldwide, with far fewer species in temperate zones. The subfamilies of Aleyrodidae currently recognized are the extinct Bernaeinae SHCHERBAKOv, 2000, and the recent ones Aleurodicinae QUAINTANCE et BAKER, 1913, Aleyrodinae WESTWOOD, 1840 and Udamoselinae ENDERLEIN, 1909 (DROHOJOWSKA \& SZWEDO 2011a, 2011b, 2013a, 2013b, 2015); the taxonomic status of the last mentioned is disputed (SHCHERBAKOV 2000, MARTIN 2007)

The fossil record of whiteflies stretches back to the Jurassic (SHCHERBAKOV 2000, DROHOJOWSKA \& SZWEDO 2015). Several taxa have been described from Lower Cretaceous amber of Lebanon (SCHLEE 1970, DroHOJOWSKA \& SZWEDO 2013a, 2015), early Eocene amber of Oise, France (DROHOJOWSKA \& SZWEDO 2013b) and Eocene Baltic amber (MENGE 1856, DROHOJOWSKA \& SZWEDO 2011b). A few other fossils are reported from Cretaceous, Palaeogene and Neogene sedimentary rocks and fossil resins (WEIGELT 1940, RIETSCHEL 1983, POINAR 1992, AZAR 2007, SCHMIDT et al. 2010).

With regard to Baltic amber only two species are known so far: 'Aleyrodes' aculeatus MENGE, 1856, a taxon of unclear status, and Paernis gregorius DROHOJOWSKA \& SZWEDO, 2011, representing the Aleurodicinae subfamily (DROHOJOWSKA \& SZWEDO 2011b).

\section{Acknowledgements}

We wish to thank Mrs Marzena ZMARZŁY for the pencil drawings of the specimen.

\section{MATERIAL AND METHODS}

A Nikon MZ1500 stereoscopic microscope and a Nikon Microphot-FX (objective lenses from $4 \times$ to $40 \times$ ) equipped with a camera lucida and changeable direct and transmitted light were used for the microscopic examination. Measurements are approximate because of the state of preservation of the inclusion, its shrivelling in hardening resin, and possible optical deformations. The photographs were taken using the Nikon Microphot-FX with a Nikon Eclipse E 600 digital camera and Lucia ${ }^{\circledR}$ software, and adjusted using Adobe ${ }^{\circledR}$ Photoshop Elements 6.0.

The general lack of descriptions of extant adult whiteflies makes the description of fossil taxa challenging, as no descriptive 'template' is available. In selecting the features, we have followed suggestions from available publications, mainly SCHLEE (1970) and MARTIN (2007). The terminology of the thoracic sclerites is according to DROHOJOWSKA \& SZWEDO (2011a), the venation nomenclature follows the suggestions of SHCHERBAKOV 
(2000) and the measurements are in accordance with the model proposed by MARTIN (2007).

\section{SYSTEMATICS}

Order Hemiptera LiNNAEUS, 1758

Suborder Sternorrhyncha AMYOT et SERVILLE, 1843

Infraorder Aleyrodomorpha CHOU, 1963

Family Aleyrodidae WESTWOOD, 1840

Subfamily Aleurodicinae QUAINTANCE et BAKER, 1913

\section{Rovnodicus DROHOJOWSKA et SzWEDO, gen. n.}

\section{Type species}

Rovnodicus wojciechowskii sp. n.; by monotypy and present designation.

\section{Etymology}

The generic name is derived from the locality name Rovno combined with the whitefly genus name Aleurodicus. Gender: masculine.

\section{Diagnosis}

Antennae 6-segmented (as in Paernis DrohoJOWSKA et SzWEDO, 2011), $2^{\text {nd }}$ antennomere bulbous ( $2^{\text {nd }}$ antennomere elongate in Paernis), antennomeres 1-5 separated (as in Paernis), flagellum short and acute (remaining segments fused, in the form of a narrow flagellum, longer than half the combined length of the preceding segments in Paernis); $3^{\text {rd }}$ antennomere the longest (as in Aleurodicus and Paernis); $3^{\text {rd }}$ to $5^{\text {th }}$ antennomeres of similar thickness; $4^{\text {th }}$ antennomere longer than $5^{\text {th }}$, terminal portion of antenna distinctly tapering apicad; head with anterior margin straight, lateral margins diverging posteriad (as in Clodionus); with lateral ocelli visible from above, placed slightly posteriad of half of compound eyes length.

\section{Description}

Head with compound eyes narrower than pronotum. In dorsal view vertex subtrapezoid, anterior margin almost straight, about $1 / 2$ of posterior margin width; lateral margins straight diverging posteriad; posterior margin slightly and widely triangularly incised. Disc of vertex flat, with shallow median groove, reaching anterior margin. Lateral ocellus above the compound eye, visible from above, placed posteriad of half of compound eye length. 
Compound eyes not divided. Base of antenna in front of compound eye, at about $1 / 2$ of compound eye height. Basiantennomere short, cylindrical, $2^{\text {nd }}$ antennomere bulbous; antennae with basal 5 segments separated and apical segments fused as short flagellum, with short filament terminalis; $2^{\text {nd }}, 3^{\text {rd }}, 4^{\text {th }}$ and $5^{\text {th }}$ segments without setae. Frontoclypeus slightly swollen. Rostrum reaching mesocoxae.

Pronotum short, collar-like, arcuate, slightly longer in lateral portions than in middle, slightly wider than width of head with compound eyes. Mesopraescutum triangular, tapering posteriad, with anterior margin arcuate. Mesoscutum covered with bubbles of gas. Mesoscutellum subquadrangular in median portion, longer in middle than at sides; lateral portions narrow, arcuately diverging anteriad. Mesopostnotum triangular in median portion, slightly shorter than mesopraescutum, lateral portions not visible. Details of metascutum not visible. Metascutellum as narrow arcuate band, diverging anteriad, slightly widened in median portion.

Legs. Proleg with femur shorter than tibia, protibial about as long as combined length of tarsomeres. Tarsus two segmented, basitarsomere and distitarsomere of similar length, tarsal claws distinct, paronychium not visible. Mesoleg similar to proleg. Metaleg not visible.

Forewing narrow; anterior margin straight at base, arcuate in apical half, anteroapical angle widely arcuate, apical margin arcuate, posteroapical angle angulate, posterior margin almost straight, claval margin widely angulate. Margins of forewing tuberculate, with short setae. Stem Sc+R straight, slightly diverging from costal margin, forked at half of forewing length; branch $\mathrm{R}_{1}$ short, not reaching costal margin; branch Rs straight at base, directed towards middle of apical margin, slightly arcuate in apical portion, not reaching margin; stem $\mathrm{CuA}$ not visible; stem CuP straight; apex of clavus slightly exceeding basal $1 / 3$ of forewing length.

Hind wing narrow, anterior margin convex at base, anterior margin arcuate, anteroapical angle widely arcuate, apical margin acutely rounded, posterior margin widely arcuate, posterior margin shallowly concave. Margins of hind wing tuberculate. Stem Sc+R straight, only wavy at apex, reaching apex.

Abdomen slightly shorter than combined length of head and thorax. Ovipositor composed of triangular gonapophyses, with setose apex. 

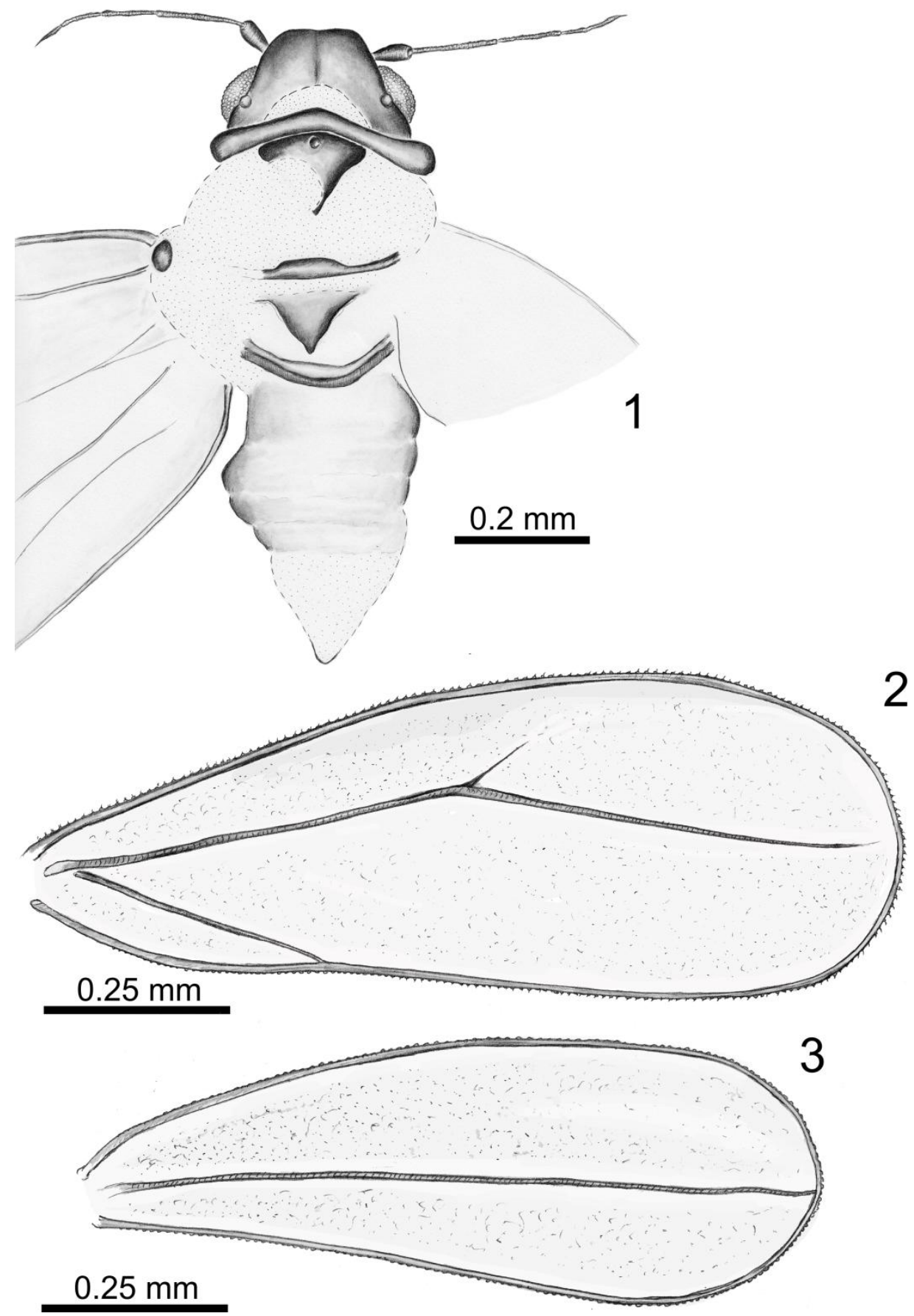

Figs 1-3. Rovnodicus wojciechowskii gen. sp. n.: 1 - body, dorsal view, 2 - forewing, 3 -hindwing. 

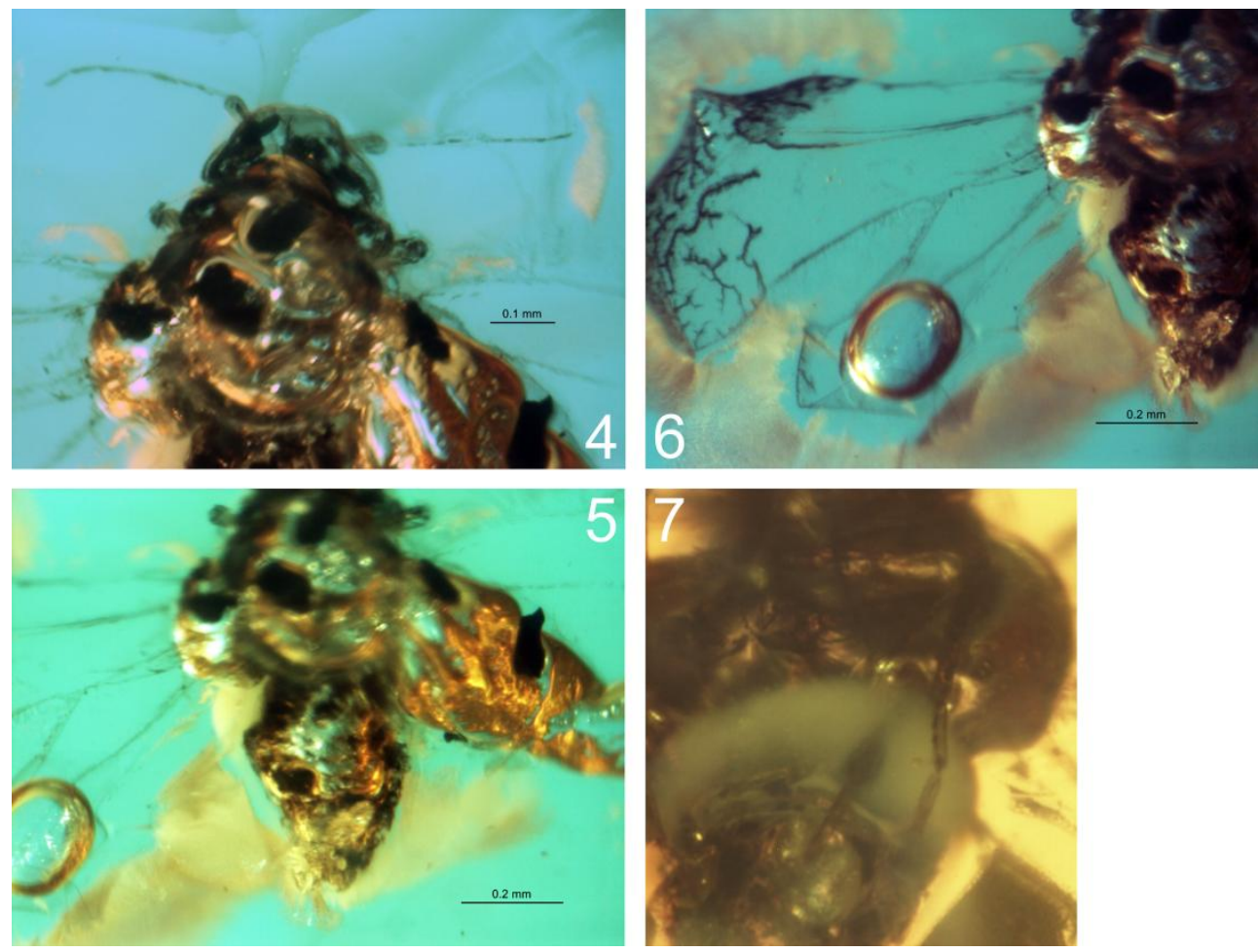

Figs 4-7. Rovnodicus wojciechowskii gen. sp. n.: 4 - anterior portion of body, dorsal view, 5 - abdomen, dorsal view, 6 - left forewing and hindwing, 7 - proleg and visible portion of mesoleg.

\section{Rovnodicus wojciechowskii DROHOJOWSKA et SZWEDO, sp. n.}

(Figs. 1-7)

\section{Type material}

Holotype, female. Specimen No.SIZK-K-75070; Rovno amber, coll. Schmalhausen Institute of Zoology, Ukrainian Academy of Sciences, Kiev, Ukraine.

Preservation. Specimen not perfectly preserved, partly covered dorsally with bubbles of gas, right forewing and hindwing creased, ventral portion of body covered with bubbles of gas, partly hidden under a milky veil.

\section{Etymology}

The specific epithet is dedicated to Professor Wacław WOJCIECHOWSKI, the eminent Polish specialist on aphids. 


\section{Diagnosis}

Anterior margin of head straight, lateral margins diverging posteriad. Antennae with basal 5 antennomeres separated and apical segments fused as short flagellum, with short filament terminalis; $2^{\text {nd }}, 3^{\text {rd }}, 4^{\text {th }}$ and $5^{\text {th }}$ antennomeres without setae. Tegmen with angle between $R_{1}$ and Rs about $45^{\circ}$.

\section{Description}

Measurements: for the basic measurements of main body parameters, see Table 1.

Colouration (in amber). Body brown, thorax slightly darker, hind wings uniformly yellowish; legs and abdomen with pygofer and forceps brown.

Table 1. Measurements of the specimen.

\begin{tabular}{|l|c|}
\hline \multicolumn{1}{|c|}{ Maesurement } & mm \\
\hline Body length total (including forceps) & 0.93 \\
\hline Head length in mid line & 0.11 \\
\hline Head with width of compound eyes & 0.28 \\
\hline Vertex width & 0.21 \\
\hline Forewing length & 1.17 \\
\hline Forewing width & 0.44 \\
\hline Hind wing length & 0.98 \\
\hline Hind wing width & 0.35 \\
\hline
\end{tabular}

\section{Age and occurrence}

Eocene (Lutetian-Priabonian), Baltic amber, Rovno deposit, Ukraine. The age of Baltic amber is still disputed, but a Middle Eocene (Lutetian) age is postulated (WEITSCHAT $\&$ WiCHARD 2010). PERKOVSKY et al. (2007) argued in favour of such an estimate, stating their preference for the Upper Eocene (Bartonian/Priabonian, $37.7 \pm 3 \mathrm{Ma}$ ) age of the Prussian Formation. The same age is suggested for amber deposited in Ukraine (PERKOVSKY et al. 2007), but the deposit seems to be mixed in origin - partly autochthonous, partly allochthonous.

\section{DISCUSSION}

The systematics of whiteflies is currently based almost solely on the puparial stage, and adults can be identified only rarely. This is exemplified by analysis of relationships within the Aleyrodinae (MANZARI \& QUICKE 2006), undertaken with the use of only a few adult 
characters. The focus on puparial stages, with many characters untested for their importance and significance, has not encouraged systematists to become involved with the group. The structure of the adults is the largest area of ignorance concerning whitefly taxonomy. Whiteflies studies suffer from a serious history, which has undoubtedly diverted the attentions of researchers elsewhere (MARTIN 2003). The general lack of descriptions of extant adult whiteflies makes the description of fossil taxa especially challenging. This is also one of the hindrances in studies of extinct whiteflies preserved in fossilized resins and as imprints in sedimentary deposits. Although fossil adult Aleyrodidae are well represented in collections, they have been poorly researched.

The first whitefly taxon from the Eocene Baltic amber to be described is 'Aleyrodes' aculeatus MENGE, 1856. The original description by MENGE (1856) is very enigmatic, the species was never illustrated, and the type specimen seems to have been lost. In discussing the taxon and its placement, DROHOJOWSKA \& SZWEDO (2011b) proposed to treat 'Aleyrodes' aculeatus MENGE, 1856 as member of Aleyrodidae without a subfamilial assignation and only formally placed in the genus Aleyrodes LATREILLE, 1796.

The second species reported from Baltic amber is Paernis gregorius DROHOJOWSKA et SzWEDO, 2011, representing the Aleurodicinae subfamily (DROHOJOWSKA \& SZWEDO 2011b). The newly described genus and species Rovnodicus wojciechowskii gen. n., sp. n. is also to be placed in the Aleurodicinae. Representatives of this subfamily have been reported from early Eocene Oise amber from France (DROHOJOWSKA \& SZWEDO 2013a) and Lower Cretaceous Lebanese amber (DROHOJOWSKA \& SZWEDO 2013b, 2015). Rovnodicus wojciechowskii gen. n., sp. n. is the first whitefly reported from Baltic amber from deposits in Rovno, Ukraine. The present-day distribution of the subfamily Aleurodicinae is restricted mainly to the Neotropical and Australasian regions (MOUND \& HALSEY 1978, MARTIN $\&$ Mound 2007, Evans 2008). The age and origin of the Baltic amber deposits in northwestern Ukraine is still controversial. Recent interpretations (BOGDASAROV 2010; PERKOVSKY et al. 2010) make it contemporaneous with the Baltic amber from the Gulf of Gdańsk. The question of the autochthonous or allochthonous origin of the Rovno amber deposit has yet to be definitively resolved (BOGDASAROV 2006, 2010). The sedimentary basin source of Rovno amber is regarded as being independent from that of Baltic amber (PERKOVSKY et al. 2007, DLUSSKY \& RASNITSYN 2009). The amber in the Rovno region is found the in Lower Oligocene Mezhygorje Formation but also in the Upper Eocene Obukhov Formation. There is evidence that amber deposited in the Rovno region comes, at least partially, from the Ukrainian Shield (PERKOVSKY et al. 2010). It must be pointed out, however, that amber deposited in the Gulf of Gdańsk area, the Rovno region in Ukraine and the Bitterfeld area in Germany is the same amber belonging to the Baltic amber group. The observed differences in composition seem to reflect ecological, environmental and taphonomic conditions rather than the age of the amber (SZWEDO \& SONTAG 2013). The 
suggested collective description for the main type of resin (succinite) found in this vast area is that it is amber from the Baltic-Dniepr amberiferous province (BOGDASAROV 2010).

The period of formation of resin deposited as Baltic amber also fell in the times of Eocene Thermal Maximum (ETM2). This period was one of the triggers for diversification and origination of modern Aleyrodidae (DROHOJOWSKA \& SZWEDO 2015), which is also confirmed by the data and interpretations presented by BOYKIN et al. (2013). Rovnodicus wojciechowskii gen. n., sp. n. is one of the few Aleurodicinae from the Eocene; one may assume it to be one of the species related to these climatic and biotic events. The forests on the southern coasts of the Eocene epicontinental sea that were exuding the resin subsequently transformed into Rovno amber were notophyllous evergreen forests (KVAČEK 2010). The Rovno amber forest is thought to represent the flora of more xeric environments than that of the Baltic amber forest. PERKOVSKY et al. (2010) considered that flora to be a mixture of tropical and subtropical plants with some temperate zone flora, including Lauraceae, Myrtaceae, Proteaceae and Moraceae. Most whiteflies utilize angiosperm hosts (MOUND 1984, Mound \& HALSEY 1978, Evans 2008), and the plants reported from this area lie within the trophic range of whiteflies.

Too little is known for the moment about the Aleyrodidae from Gulf of Gdańsk and Rovno amber, and, surprisingly, no records of Aleyrodidae from the Bitterfeld area are known; drawing inferences about the similarities or dissimilarities of these faunas with respect to whiteflies is therefore premature. Moreover, there is an unconfirmed report of Aleyrodidae from the Eocene - the species 'Aleurochiton eozaenicus', mentioned by WEIGELT (1940: 347) as a puparium on leaf from the Middle Eocene Fossillagerstätte Geiseltal in Germany. This name appears to be nomen nudum.

The finding of Aleyrodidae (Aleurodicinae) in amber from the Rovno region is another indication of how fossils are important for providing opportunities for further investigations and comparative studies, resulting in a better knowledge and understanding of Aleyrodidae diversity and morphological disparity.

\section{REFERENCES}

AZAR D. 2007. Preservation and accumulation of biological inclusions in Lebanese amber and their significance. Comptes Rendus Palevol 6(1): 151-156.

Bogdasarov M.A. 2006. Problem of amber and other fossil resins formation. Geologomineralogichni Visnik 16(2): 17-26. (in Russian)

Bogdasarov M.A. 2010. Amber and other fossil resins of Eurasia: Monograph. Brestskii Gosudarstvennyï Universitet imieni A.S. Pushkina, Brest. (in Russian)

Boykin L.M., Bell C.D., Evans G., Small I., De Barro P.J. 2013. Is agriculture driving the diversification of the Bemisia tabaci species complex (Hemiptera: Sternorrhyncha: 
Aleyrodidae)?: Dating, diversification and biogeographic evidence revealed. BMC Evolutionary Biology 13: 228.

DLuSSKY G.M., Rasnitsyn A.P. 2009. Ants in the Upper Eocene amber of central and eastern Europe. Paleontological Journal 43(9): 1024-1042.

Drohojowska J., SzwEdo J. 2011a. A new whitefly from Lower Cretaceous Lebanese amber (Hemiptera: Sternorrhyncha: Aleyrodidae). Insect Systematics and Evolution 42(2): 179-196.

DrohojowsKa J., SzWEdo J. 2011b. New Aleyrodidae (Hemiptera: Sternorrhyncha: Aleyrodomorpha) from the Eocene Baltic amber. Polish Journal of Entomology 80(4): 659-677.

DrohojowsKa J., SzWEdo J. 2013a. Whiteflies (Hemiptera: Sternorrhyncha: Aleyrodidae) from the Lowermost Eocene Oise amber. Zootaxa 3636(2): 319-347.

Drohojowska J., Szwedo J. 2013b. Gapenus rhinariatus gen. sp. n. from the Lower Cretaceous amber of Lebanon (Hemiptera: Sternorrhyncha: Aleyrodidae). [in:] D. AZAR, M.S. ENGEL, E. Jarzembowski, L. Krogmann, A. Nel, J. Santiago-Blay (eds.). Insect Evolution in an Amberiferous and Stone Alphabet. Proceedings of the $6^{\text {th }}$ International Congress on Fossil Insects, Arthropods and Amber. Brill, Leiden-Boston, 99-110.

DrohojowsKa J., Szwedo J. 2015. Early Cretaceous Aleyrodidae (Hemiptera: Sternorrhyncha) from the Lebanese amber. Cretaceous Research 52B: 368-389.

Evans G.A. 2008. The whiteflies (Hemiptera: Aleyrodidae) of the world and their host plants and natural enemies. USDA/Animal Plant Health Inspection Service (APHIS). Last Revised: September 23, 2008. 703 pp. Internet: http://www.sel.barc.usda.gov:591/1WF/World-WhiteflyCatalog.pdf

KVAČEK Z. 2010. Forest flora and vegetation of the European early Palaeogene - a review. Bulletin of Geosciences 85(1): 63-76.

MARTIN J.H. 2003. Whiteflies (Hemiptera: Aleyrodidae) - their systematic history and the resulting problems of conventional taxonomy, with special reference to descriptions of Aleyrodes proletella (LinNAEus, 1758) and Bemisia tabaci (GenNAdius, 1889). Entomologist's Gazette 54: 125-136.

MARTIN J.H. 2007. Giant whiteflies (Sternorrhyncha, Aleyrodidae): a discussion of their taxonomic and evolutionary significance, with the description of a new species of Udamoselis ENDERLEIN from Ecuador. Tijdschrift voor Entomologie 150(1): 13-29.

Menge A. 1856. Lebenszeichen vorweltlicher im Bernstein eingeschlossener Thiere. Programm öffentlichen Prüfung der Schüler der Petrischule, Danzig. Verlag A.W. Kafemann, Danzig $[1]+1-32$.

Mound L.A. 1984. Zoogeographical distribution of whiteflies. [in:] M. HARRIS (ed.). Current Topics in Vector Research, Volume 2. Praeger Publishers, New York, NY, USA, 185-197.

Mound L.A., HALSEY S.H. 1978. Whitefly of the World: a systematic catalogue of the Aleyrodidae (Homoptera) with host plant and natural enemy data. British Museum (Natural History) and John Wiley \& Sons, Chichester \& New York.

Perkovsky E.E., Zosimovich V.Yu., Vlaskin A.P. 2010. Rovno amber. In: D. Penney (ed.). Biodiversity of fossils in amber from the major world deposits. Siri Scientific Press, Manchester, 116-136. 
Perkovsky E.E., Rasnitsyn A.P., Vlaskin A.P., TARAschuk M.V. 2007. A comparative analysis of the Baltic and Rovno amber arthropod faunas: representative samples. African Invertebrates 48(1): 229-245.

POINAR G.O. Jr. 1992. Life in amber. Stanford University Press, Stanford, CA.

RIETSCHEL S. 1983. Aleurochiton petri n. sp., eine Mottenschildlaus (Homoptera, Aleyrodina) aus dem Pliozän von Neu-Isenburg, Hessen. Carolinea 41: 97-100.

SCHLEE D. 1970. Verwandtschaftsforschung an Fossilien und rezenten Aleyrodina (Insecta, Hemiptera). Stuttgarter Beiträge zu Naturkunde 213: 1-72.

Schmidt A.R., Perrichot V., Svojtka M., Anderson K.B., Belete K.H., Bussert R., Dörfelt H., Jancke S., Mohr B., Mohrmann E., Nascimbene P.C., Nel A., Nel P., Ragazzi E., Roghi G., Saupe E.E., Schmidt K., Schneider H., Selden P.A., VÁvra N. 2010. Cretaceous African life captured in amber. Proceedings of the National Academy of Sciences of the United States of America 107(16): 7329-7334.

SHCHERBAKOv D.E. 2000. The most primitive whiteflies (Hemiptera; Aleyrodidae; Bernaeinae subfam. nov.) from the Mesozoic of Asia and Burmese amber, with an overview of Burmese amber hemipterans. Bulletin of the Natural History Museum, Geology Series 56(1): 29-37.

Szwedo J., Sontag E. 2013. The flies (Diptera) say that amber from the Gulf of Gdańsk, Bitterfeld and Rovno is the same Baltic amber. Polish Journal of Entomology 82(4): 379-388.

WeIGELt J. 1940. Der heutige Stand der Geiseltalforschung. Naturwissenschaften 22: 343-350.

Weitschat W., Wichard W. 2010. Baltic amber. In: Penney D. (ed.), Biodiversity of fossils in amber from major world deposits. Siri Scientific Press, Manchester, 80-115.

Received: 3 July 2015

Accepted: 3 August 2015 